Papers and Proceedings of the Royal Society of Tasmania, Volume 114, 1980.

(ms. received 5.2 .1979$)$

\title{
GEOLOGY OF THE BLUFF HILL POINT REGION
}

by P.G. Lennox

Geological Survey of Tasmania; formerly Geology Department, University of Tasmania

(with five text figures and one plate)

ABSTRACT

LenNox, P.G., 1980 (31 v): Geology of the Bluff Hill point region. Pap. Proe. R.

Soc. Tasm., 114: 69-79 (inc. one plate). ISSN 0080-4703. Geological Survey of

Tasmania, Department of Mines, Hobart, Tasmania, Australia.

The cross-bedded and ripple-marked, supermature guartz-arenite sequence outcropping at Bluff Hill point encloses a 125 metre + thick dominantly mudstone sequence. Sedimentary features include graded bedding, scour and fill structures, pseudonodules, clastic dykes and load cast structures of various morphologies. This sequence, which is of a very low metamorphic grade, displays two phases of folding, each phase associated with cleavage. The earlier phase consists of folds with hingelines trending north-westerly. The later fold phase has hingelines trending north to north-north easterly.

Similarities with the Rocky Cape Group exposed between Port Latta and Jacobs Boat Harbour have been noted, although there are differences in cross-bedding patterns and relationships between the fold phases.

\section{INTRODUCTION}

Geological reconnaissance of the Bluff Hill Point - Trowutta area (Longman and Matthews 1962) resulted in the subdivision of the Late Proterozoic rocks into a sequence of interbedded quartzite, shale, sub-greywacke and rare conglomerate (north of the Arthur River) and an underlying sequence of interbedded green chloritic shale and quartzite (south of the Arthur River). This Late Proterozoic, sequence of very low metamorphic grade is considered to be a correlate of the Rocky Cape Group which crops out between Port Latta and Jacobs Boat Harbour (Williams and Turner 1974; Gee 1967, 1968, 1971).

The purpose of this paper is to describe the sedimentology and structural geology of the Bluff Hill Point region, to compare this region with coastal exposures from Green Point to Temma and to test the validity of past regional correlations.

The area is accessible during summer along sand tracks off the road from Marrawah to the Arthur River (see figure 1).

\section{SEDIMENTOLOGY AND STRATIGRAPHY}

The sequence between Church Rock and Bluff Hil1 Point consists of cross-bedded quartz-arenite beds. Cross-bedding is generally of planar type although some trough cross-bedding is present. The tops of beds are often ripple-marked. The quartzarenite sequence conformably overlies a mudstone sequence in excess of 125 metres thick, exposed between the Point designated A [BQ995573] and G [BQ998576] (see figure 2).

Rocks typical of the quartz-arenite sequence crop out at Church Rock and locality $G$ and are well-bedded, well-sorted, white, quartz-arenite which display a sugary lustre on fresh broken faces. Typical examples are specimens $77 / 294 \mathrm{H}$, I which are well cemented, indurated and contain up to $3 \%$ of opaque minerals. Slides referred to 
Geology of the Bluff Hill Point Region

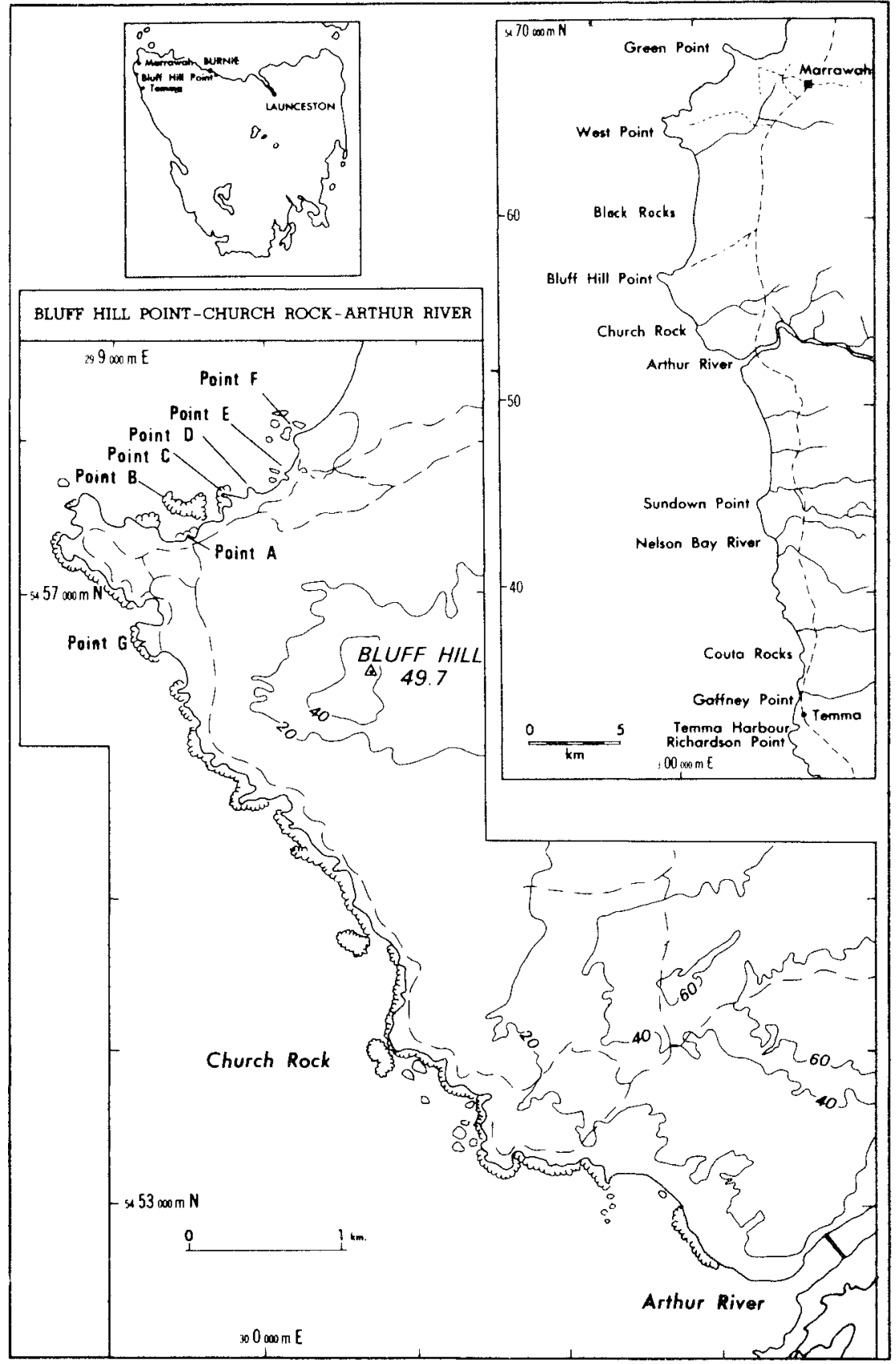

FIG. 1.- Locality map illustrating position of subject area within Tasmania, Marrawah to Temma coastal features and Bluff Hill Point to Arthur River. 
P.G. Lennox

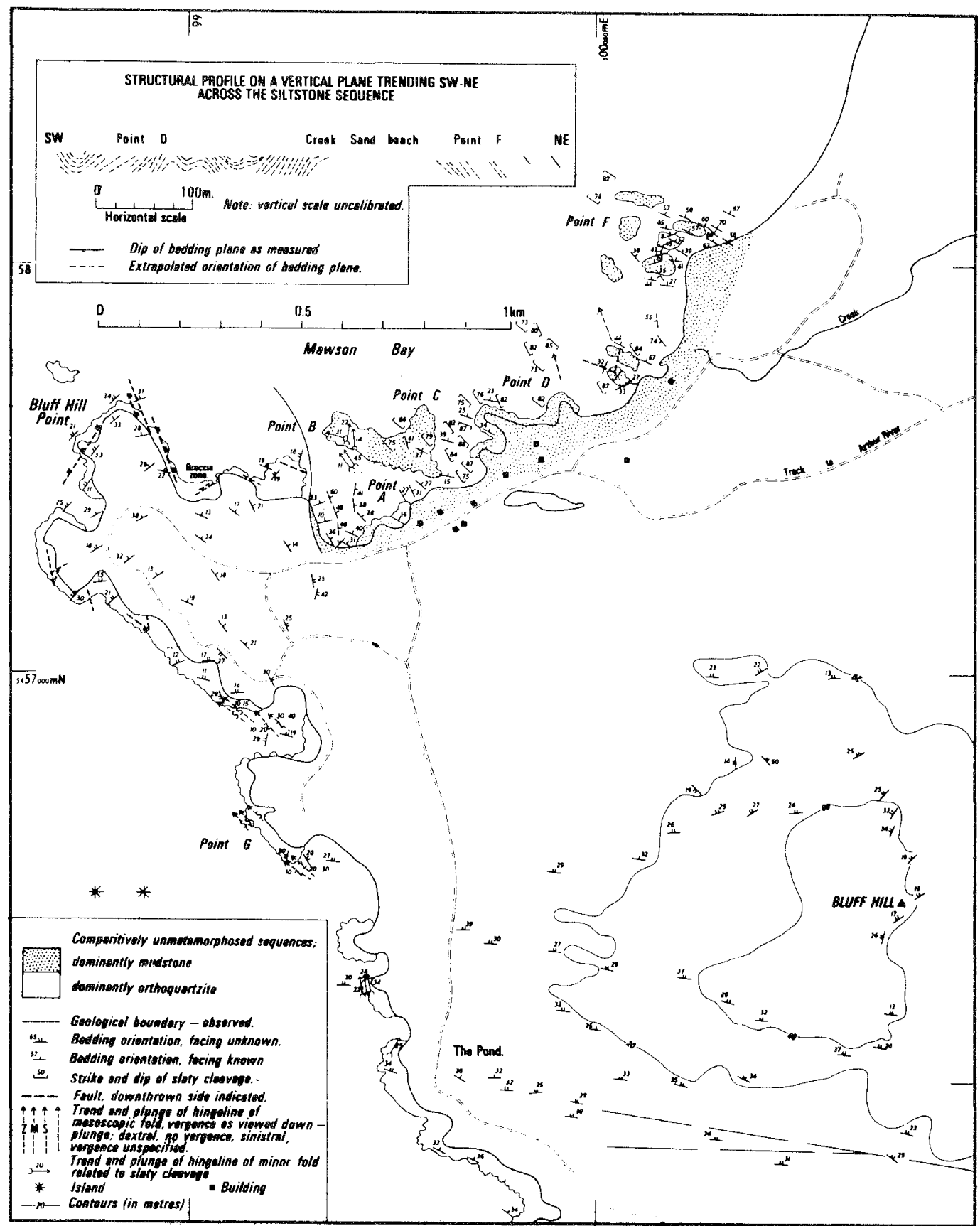

FIG. 2.- Geology at Bluff Hill Point. 
Geology of the Bluff Hill Point Region

in the text with a number of the form $77 / 2941$ are retained in the Mines Department collection whilst those with a number of the form 49529 are retained in the collection of the University of Tasmania. In specimen 77/2941 discrete acicular sericite grains are usually aligned parallel to the quartz grain boundaries but occasionally the sericite grains form matted fibrous inter-growths between and within quartz grains. Sericite is less common in specimen $77 / 394 \mathrm{H}$ where it occurs as clustered fibrous sericite up to 0.08 min long in beards at opposite ends of quartz grains. Overgrowths of quartz are formed in the Church Rock specimen and are marked by the dusty nature of quartz grain margins.

A fine-grained dolomitic-mudstone with embayed dolomite sparite clasts (up to 4 mm diameter) and zoned chert clasts indicates a paragnetic sequence as follows:carbonate predominantly dolomite, silification and a second phase of dolomitisation. A part of this paragenetic sequence is displayed in a fault-breccia occurring at locality D [BQ997574] where chert bodies in a vein network of chert are replaced in part by dolomite grains approaching $0.5 \mathrm{~mm}$ in diameter.

Sedimentary features include graded bedding, scour and fill structures, pseudonodules, clastic dykes, lenticular beds with cross-lamination, load cast structures of various morphologies and possible slump structures.

Scour and fill structures with continuous bedding laminations within the fil1, crop out on the point designated A [BQ995573] on figure 2 whilst at B [BQ996575] straight to gently curved channels up to $50 \mathrm{~mm}$ and $0.5 \mathrm{~m}$ long show multiple scouring and truncated fill laminae (see plate 1, fig. 1). Pseudonodules vary from non-laminated bulbous forms (one to three centimetres across) shown in plate 1 (figure 2) from locality A to laminated, cuspate bodies as exposed at B in plate l (figure 3). Clastic dykes occur abundantly in certain horizons throughout the succession. They are predominantly planar in form and may be aligned in the cleavage direction. Extensive polygonal clastic dyke development exposed on a bedding surface at locality $D$ indicates a mudcrack-origin.

The isolated, semi-elliptical, double-hinged feature with micro-folded inner bedding laminations and scoured upper surface at B (plate 1, figure 4) may have formed by loading during and after sedimentary dewatering or by slumping of a cross-bedded sequence (Hendry and Stauffer 1975). Slumping involving movement of a dense, sedimentladen flow over the surface of the cross-bedded layers seems unlikely because of the double hinged form and scoured upper contact. The sedimentary structure in plate 1 figure 5 outcrops in a $0.5 \mathrm{~m}$ thick bed consisting of internally deformed tight to isoclinal, recumbent folds with hingelines of variable orientation and is considered to have been formed by sedimentary dewatering.

A combination of loading by the 10-20 mm thick bedded denser silty upper layers and sedimentary dewatering and erosion probably resulted in the structures illustrated in plate 1 , figures 6 and 7 .

The recumbent, tight to isoclinal fold with bevelled lower surface and unscoured upper surface on the coast between localities D and C may be of a slump origin (see plate 1 , figure 8).

Longman and Matthews (1962) divided the comparatively unmetamorphosed Precambrian on the West Coast from Marrawah to Temma into a number of formations. Their assignment of the Bluff Hill Point sequence to the interbedded quartzite, sub-greywacke and rare conglomerate beneath the Byrant Hill Quartzite is accepted.

A total of 100 measurements of cross-bedding direction were made at three stations - 


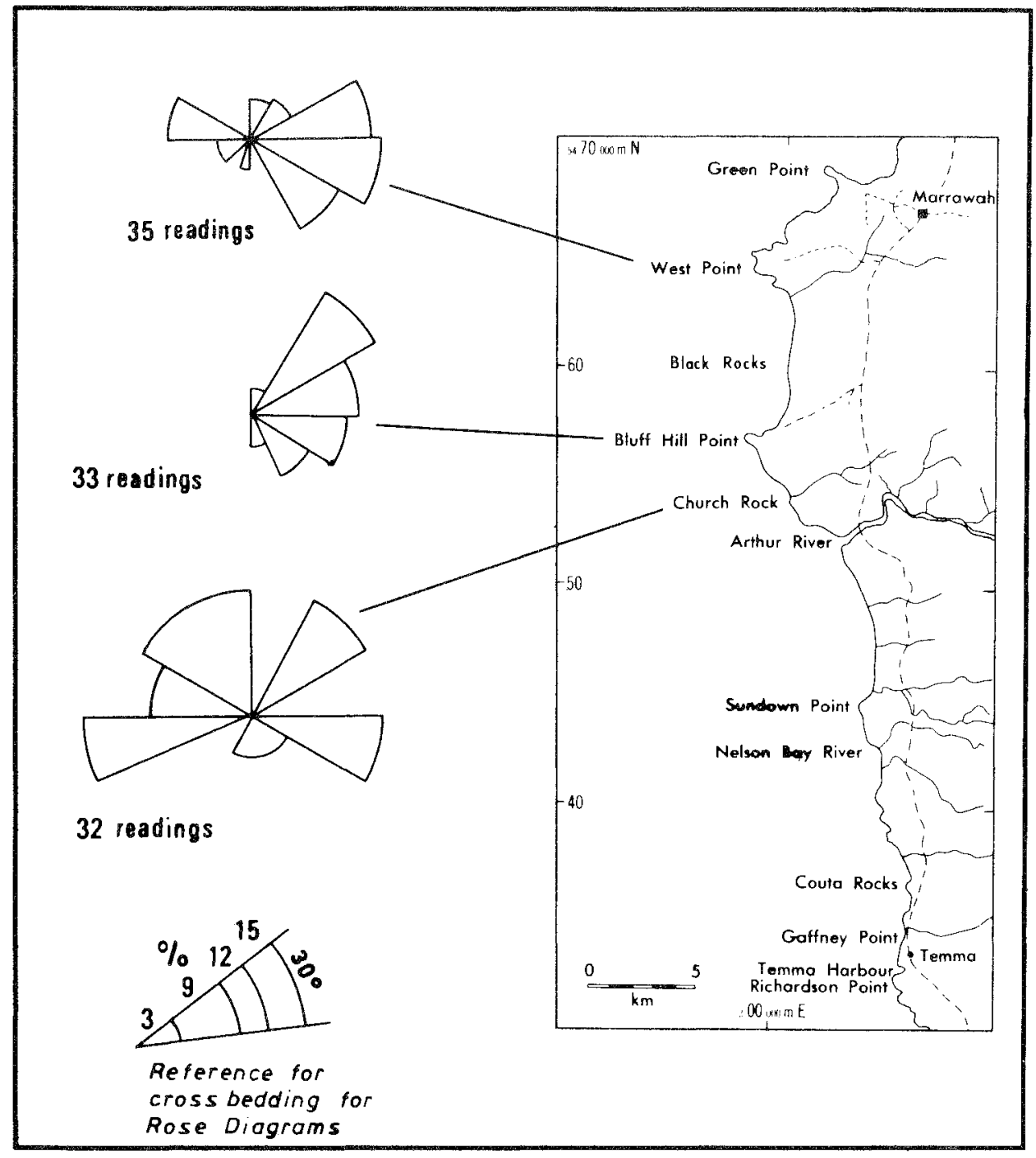

FIG. 3.- Cross-bedding directions in the quartz-arenites of West Point, Bluff Hill Point proper and Church Rock. 


\section{Geology of the Bluff Hill Point Region}

Church Rock, Bluff Hill Point and West Point, representing $10 \mathrm{~km}$ of coastline between Marrawah and the Arthur River. The structure in the Bluff Hill Point and West Point area is geometrically simple. At Bluff Hill Point the quartz-arenite sequence is folded into an open, upright, gentlymplunging anticline (half-wavelength about 600 metres). The hingeline plunges $22^{\circ}$ to $030^{\circ}$ and the axial surface is sub-paralle1 to the second cleavage. The upright anticline on West Point plunges $30^{\circ}$ to $228^{\circ}$. The axial surface is almost parallel to the first cleavage which is dominant in this area. The folds of the two phases of deformation affecting the Marrawah - Temma region are not co-axial (see structural geology section). Thus tilt-correction methods for un-rolling sedimentary lineations on plunging, cylindroidal, flexural folds do not yield the original current directions. However, tilt-corrected aximuths yield patterns which may be compared with similarly corrected azimuths determined in other regions. T'ilt-corrected azimuths for each station are grouped in 30 degree sectors and are dism played as rose diagrams as shown in figure 3. These rose diagrams do not reveal a single, consistent, well-developed mode in contrast to Gee's (1971) diagrams for the orthoquartzites of the Rocky Cape Group between Rocky Cape and Jacobs Boat Harbour.

\section{STRUCTURAL GEOLOGY}

\section{Bluff Hill Point}

Within the siltstone sequence the hingelines of the smaller folds with halfwavelengths less than two metres are contained within the surface of the primary cleavage (dips $78^{\circ}$ to $226^{\circ}$ ) which is dominant, (figures $2,4 \mathrm{c}$ and $4 \mathrm{~d}$ ). The axial surface of the large open, gently-plunging anticline (half-wavelength about 600 metres) on Bluff Hill Point is orientated subparallel to the secondary crenulation cleavage observed within the sequence (dips $76^{\circ}$ to $312^{\circ}$ ). The axial surface of the up to three metre half-wavelength, asymmetric to monoclinal, gently-plunging, open upright folds observed on the foreshore within the vicinity of point $G$ [BQ992566] are also subparallel to the dominant cleavage orientation.

The stereoplot of poles to bedding for the siltstone sequence shown in figure 4 a may indicate two possible pi-pole girdles although the spread of poles is too narrow to determine the girdle orientation. All stereoplots are lower hemisphere and are equal area projections. The pi-pole girdle formed from poles to bedding readings usually reflects the local regional fold hingeline within an area. One possible pipole girdle envisaged from the stereoplot of poles to bedding for the siltstone sequence has a hingeline within the surface of the dominant cleavage observed at Bluff Hill point (dips $78^{\circ}$ to $226^{\circ}$ ). The stereoplot of poles to bedding orientation for the orthoquartzite sequence may also possibly reflect two pi-pole girdles although the range of poles is too small to permit the girdle orientation to be determined (see figure $4 b$ ).

Slides 4529,45921 show that the poorly developed cleavage dipping $76^{\circ}$ to $312^{\circ}$ crenulates the dominant cleavage $\left(78^{\circ}\right.$ to $\left.226^{\circ}\right)$ observed at Bluff Hill Point. In outcrops an anastonosing cleavage develops near localities $\mathrm{C}$ and $\mathrm{F}$, reflecting the interaction of the two cleavages. In thin section the dominant cleavage is a lepidoblastic sericite fabric in the mudstone. This fabric is transected by narrow crenulate zones at a high angle with a minority of discrete sericite grains in the matrix aligned parallel to the crenulate zones. A quartz-wacke from Island Point (45918) shows bent detrital muscovite grains. One specimen of orthoquartzite (45930 from the cliffs 0.5 kn west of the Marrawah - Arthur River road on the Bluff Hill Point Track shown distinct incipient dissolution stringers.

Marrawah to Temma

The two cleavages observed at Bluff Hill Point occur throughout the Marrawah to Temma coastal platform exposures briefly examined by the author (figure 5 ). 

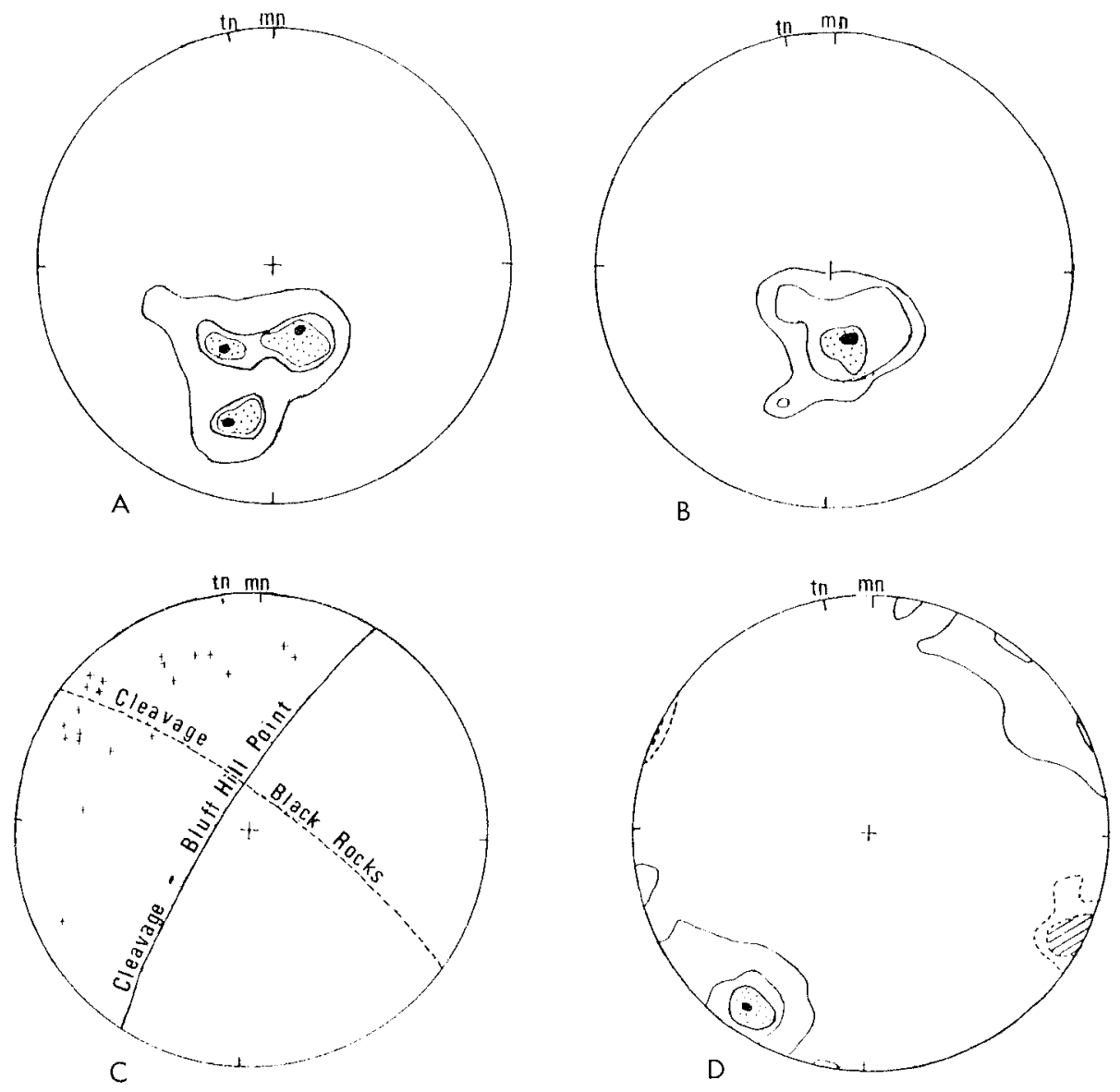

FIG. 4.- Bluff Hill point - contoured equal area projections on the lower hemisphere:-

(a) Siltstone sequence - poles to bedding 220 readings, 2-4-6-8-10-14\% per $1 \%$ area.

(b) Quartz-arenite sequence - poles to bedding 321 readings 2-4-6-8-10$16-20 \%$ per $1 \%$ area.

(c) Minor fold hingelines 24 readings. Solid line is the great circle for averaged value of second cleavage, dashed line of first.

(d) Bluff Hill Point - poles to cleavage 65 readings $2-6-10-20-30 \%$ per $1 \%$ area.

North Black Rocks - poles to cleavage 6 readings $16-32$; per $1 \%$ area. 


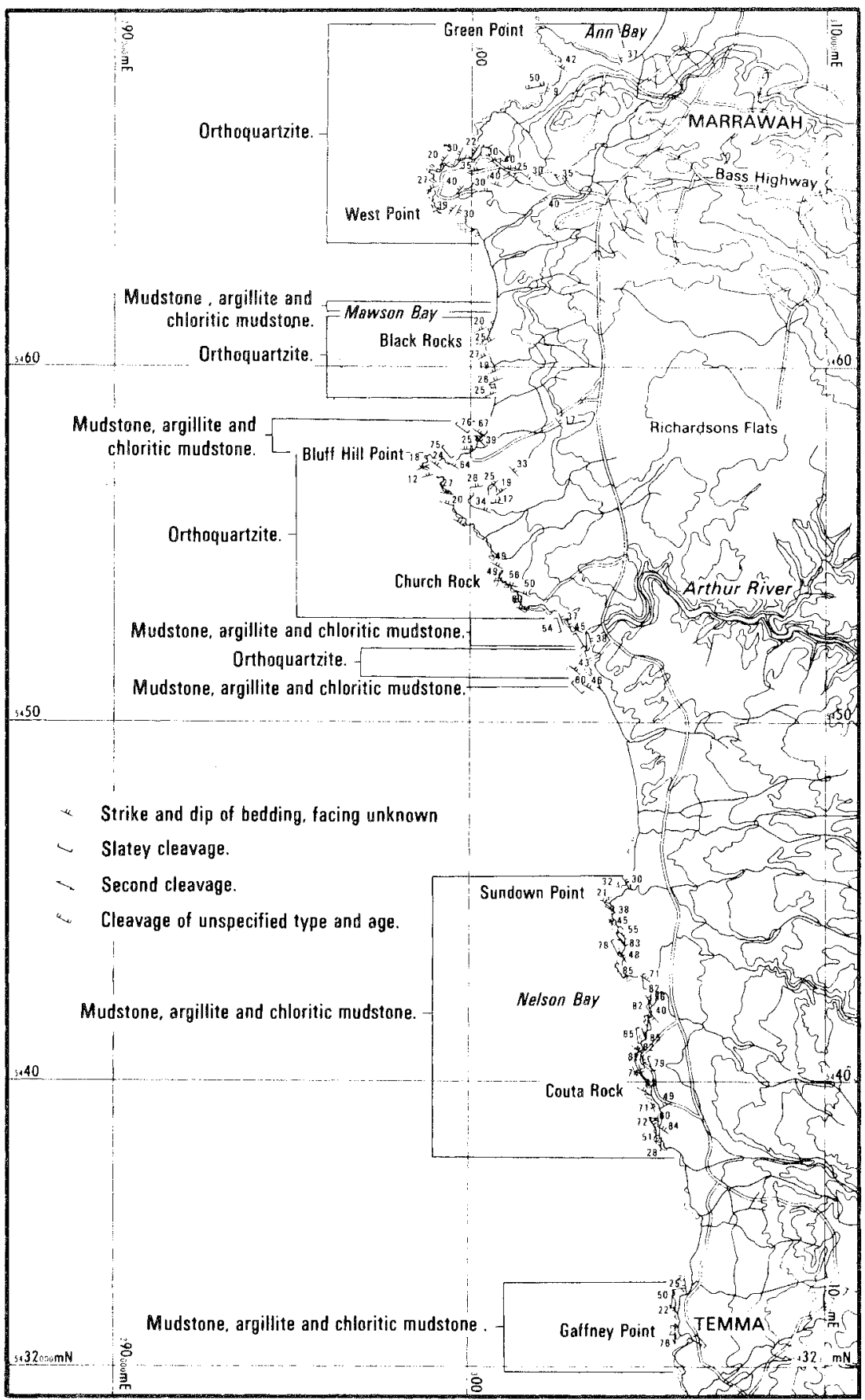

FIG. 5.- Marrawah to Terma -- coastal geoiogy 


\section{P.G. Lennox}

The West Point quartz-arenite sequence is folded into a large, open, upright, gently-plunging anticline of $2 \mathrm{~km}$ half-wavelength with a hingeline which p1unges $30^{\circ}$ to $328^{\circ}$ within the dominant primary cleavage surface observed at Bluff Hill Point.

The dark grey argillite exposed on the headlands adjacent to the Arthur River display in thin section a lepidoblastic sericite fabric at a low angle to bedding. The first cleavage bends detrital micas and is transerected by rare metamorphic white micas and discrete opaque stringers up to $0.4 \mathrm{~mm}$ long at a high angle to bedding defining the second cleavage $(77 / 839)$. The measured orientation of these two cleavages on the Arthur River headlands is similar to those observed at Bluff Hill point.

There is a progressive change in the strike of the country rock from BIuff Hill Point (NW - SE) to Temma $(N-S)$ together with a gradual steepening of the dip of the beds from north to south.

\section{SUMMARY AND CONCLUSIONS}

The Lower Palaeozoic Rocky Cape Geanticline (Williams 1978) which occupied the whole of the north-west of Tasmania contains the very low metamorphic grade Rocky Cape Group between Port Latta and Jacobs Boat Harbour. The Rocky Cape Group (Gee 1971) consists of two formations of super-mature quartz-arenite, each more than $1200 \mathrm{~m}$ thick, and formations of cleaved siltstone. The Marrawah to Temma coastal outcrops consists of super-mature quartz-arenite, chloritic-mudstone and argillite which can probably be correlated with the Rocky Cape Group (Geeibid; and Williams and Turner 1974).

Insufficient stratigraphic analyses have been completed along the entire Marrawah to Temma coastal exposures to permit a full comparison of this sequence with the Rocky Cape Group. The lithology, sedimentary features and low metamorphic state of the sequence at Bluff Hill Point are similar to parts of the Rocky Cape Group exposed between Port Latta and Jacobs Boat Harbour (Gee ibid). However, the pattern of the tiltcorrected cross-bedding with the West Coast quartz-arenite sequence does not display a single, consistent mode like those Gee ( $i b i d$. ) calculated from the quartz-arenite sequence within the Rocky Cape Group between Rocky Cape and Jacobs Boat Harbour.

Structural analysis shows that the West Coast sequence exhibits two phases of folding which both result in the development of gently-plunging-open, upright, minor (half-wavelength $2-3$ metres) to major (half-wavelength $=2 \mathrm{~km}$ ) folds. The first phase of folding resulted in the development of north-westerly plunging, symmetrical folds of $2 \mathrm{~km}$ half-wavelength and asymmetric to monoclinal, gently north-westerly plunging minor folds. The lepidoblastic sericite fabric defining the first cleavage is aligned within the axial surface of these folds. Northerly to north-north-easterly plunging folds of similar style to the first phase folds mark the second phase of folding. A cleavage which crenulates the lepidoblastic sericite fabric lies within the axial surface of the second phase folds. In comparison the Rocky Cape Group exhibits east of Rocky Cape, one phase of folding, which produced a slaty cleavage and high-angle thrusts. The plunge of these folds was increased to the north by rotation about a hinge at right angles to the axial surface. A later sub-horizontal strain-slip cleavage was developed in some localities.

\section{ACKNOWLEDGEMENTS}

This paper formed a large part of an Honours Thesis submitted to the Geology Department, University of Tasmania in 1976, a thesis supervised by Dr. C.A. Boulter. Many useful discussions have been held with P. Williams and Dr. E. Williams. My thanks for their constructive criticism of the manuscript. This paper is published with the permission of the Department of Mines. 


\section{REFERENCES}

Gee, R.D., 1967: The tectonic evolution of the Rocky Cape Geanticline in North-West Tasmania, Unpublished Ph.D. Thesis, University of Tasmania, $351 \mathrm{pp}$.

1968: A revised stratigraphy for the Precambrian of north-west Tasmania, Pap. Proc. R. Soc. Tasm., 102: 7-10.

1971: Geological atlas 1 mile series zone 7 sheet 22 (8016s) Table Cape, Exptan. Rep. geot. Sum. Tasm.

Hendry, H.E. and Stauffer, M.R., 1975: Penecontemporaneous recumbent folds in trough cross-bedding of Pleistocene sands in Saskatchewan, Canada. J. Sedim. Petrol. $45(4)$ : $932-943$.

Longman, M.J. and Matthews, W.L., 1962: The geology of the Bluff Point and Trowutta Quadrangles. Tas. Dept. Mines Technical Report 6:48-54 and 79-85.

Williams, E., 1978: Tasman Fold Belt System in Tasmania, Tectonophysics, 48: 159-205. , and Turner. N.J., 1974: Geological Atlas 1:250,000 Series sheet No. SK-55/3. Burnie, Explan. Rep. geol. Sum. Tasm.

Figure 1 : Bluff Hill Point - Point B - scour and fill structure (lens cap is $5 \mathrm{~mm}$ thick).

Figure 2 : Bluff Hill Point - Point A - pseudonodules (divisions are $100 \mathrm{~mm}$ wide).

Figure 3 : Bluff Hill Point - Point B - pseudonodules (lens cap is $5 \mathrm{~mm}$ thick).

Figure 4 : Bluff Hill Point - Point B - sedimentary dewatering structure (?), (geology pick handle is $40 \mathrm{~mm}$ thick at its base).

Figure 5 : Bluff Hill Point - Point A - sedimentary dewatering structure (?), (divisions are $10 \mathrm{~mm}$ wide).

Figure 6 : Bluff Hill Point - Point A - sedimentary dewatering structure (?), (divisions are $10 \mathrm{~mm}$ wide).

Figure 7 : Bluff Hill Point - Point B - sedimentary dewatering structures in well laminated siltstone (geology pick is $300 \mathrm{~mm}$ long).

Figure 8 : Bluff Hill Point - Point C to D - possible slump structure, (geology pick head is $20 \mathrm{~mm}$ thick). 


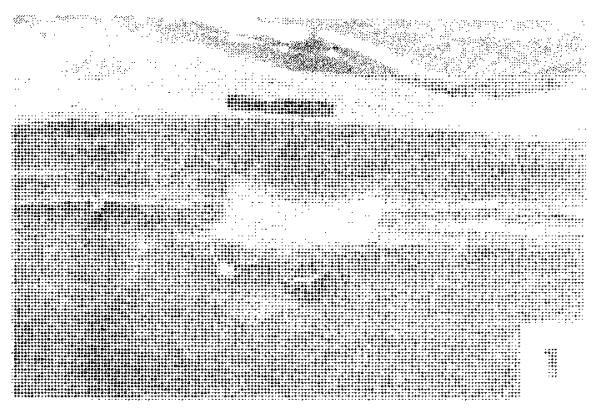

$+\cdots$
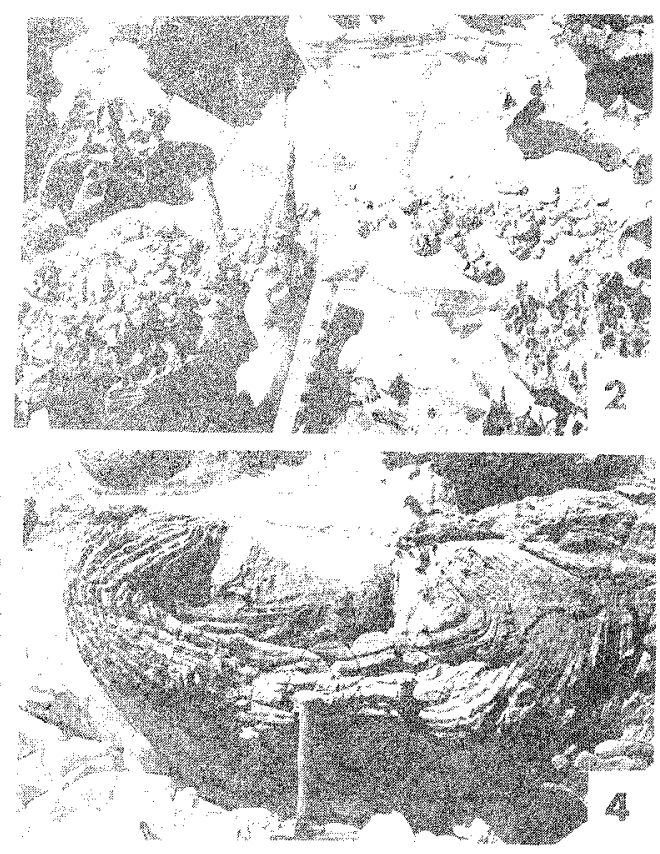
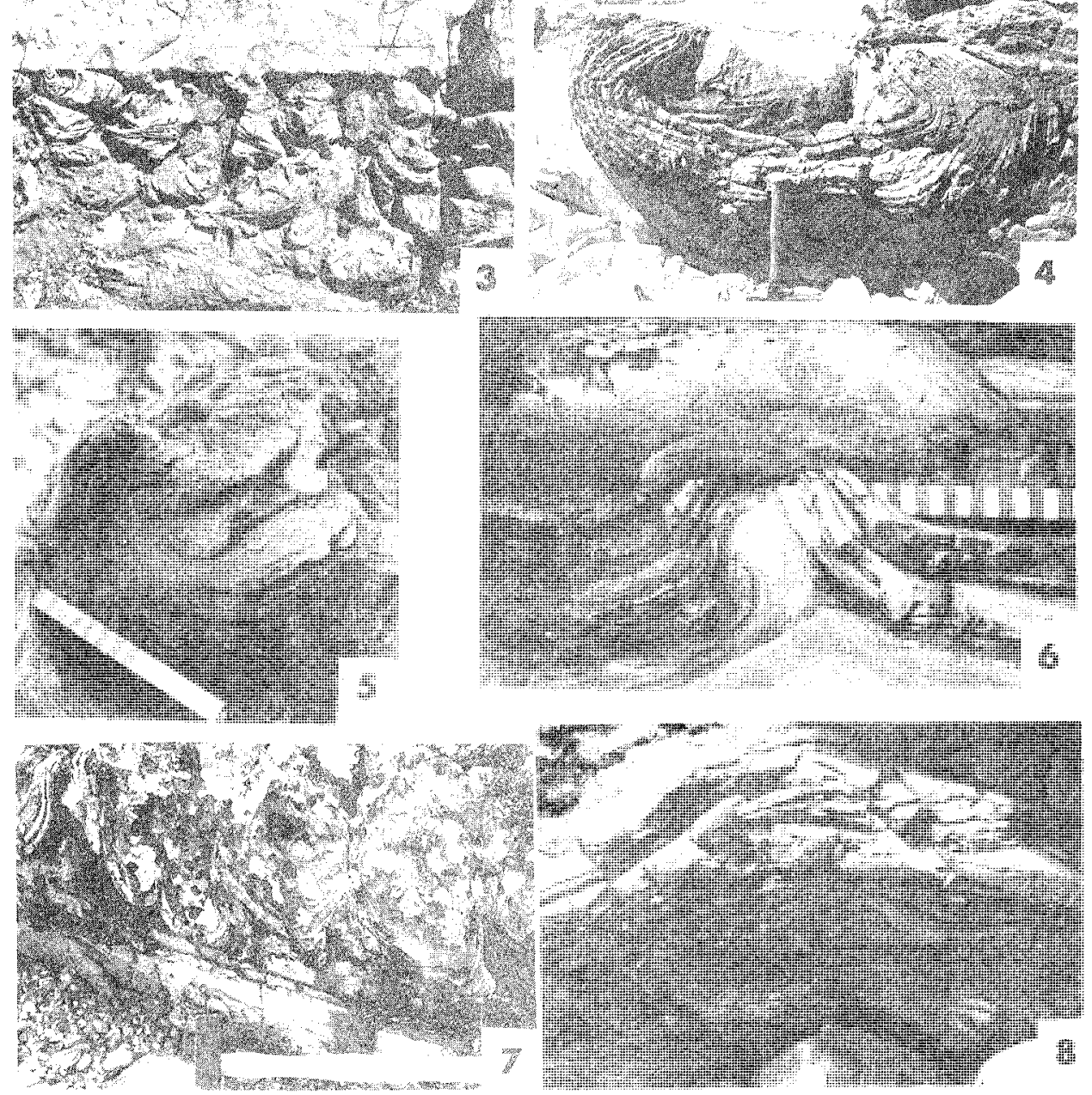

PLATE 1 